\title{
AKTIVITAS ANTIBAKTERI DAN ANTIOKSIDAN FRAKSI ETIL ASETAT KULIT BUAH SAWO (Manilkara zapota)
}

\author{
Alviera Rifka Mahmudyah*, Rolan Rusli, Adam M Ramadhan \\ Laboratorium Penelitian dan Pengembangan FARMAKA TROPIS Fakultas \\ Farmasi Universitas Mulawarman, Samarinda, Kalimantan Timur \\ *email : alvierarifka@gmail.com
}

\begin{abstract}
Abstrak
Sawo (Manilkara zapota) merupakan tanaman yang diketahui memiliki berbagai manfaat, yaitu salah satunya sebagai obat diare dan antioksidan. Penelitian ini dilakukan untuk mengetahui aktivitas antibakteri dan antioksidan dari fraksi etil asetat dari kulit buah sawo. Pada penelitian ini dilakukan ekstraksi lalu fraksinasi sehingga diperoleh fraksi etil asetat yang kemudian diuji aktivitas antibakteri dan antioksidan dengan metode KLT bioautografi. Fraksi kulit buah sawo memiliki aktivitas antibakteri pada bakteri E.coli dan S.aureus dengan berbagai perbandingan eluen heksana:etilasetat (H:E) yaitu perbandingan 2:3, 3:3, 3:4, 3:5 dan 7:3. Aktivitas antioksidan diperoleh pada eluen H:E 9:1, 8:2, 7:3, 6:4, dan 5:5.
\end{abstract}

Kata Kunci : Antibakteri, Antioksidan, Sawo, KLT Bioautografi

\section{PENDAHULUAN}

Penggunaan tanaman sebagai obat telah lama dikenal oleh masyarakat Indonesia. Penggunaan tanaman sebagai obat diperoleh melalui pengalaman empiris secara turun temurun. Penggunaan tanaman obat secara tradisional dilakukan dengan cara direbus, dimakan langsung, ataupun diperas diambil sarinya.

Penggunaan tanaman sebagai obat tradisional memiliki beberapa keuntungan, antara lain adalah relatif lebih aman, mudah diperoleh, tidak menimbulkan resistensi, dan relatif tidak berbahaya terhadap lingkungan sekitar (Sugianti, 2005). Tanaman yang telah lama dikenal penggunaannya sebagai tanaman obat di Indonesia adalah tanaman sawo (Manilkara zapota). Sawo dijadikan sebagai salah satu obat alternatif dalam pengobatan diare (Rukmana, 1997).

Sifat antioksidan dan antibakteri tanaman sawo dari bagian kulit batang sawo belum dilaporkan secara ilmiah, sehingga perlu dilakukan penelitian mengenai sifat aktivitas antioksidan dan antibakteri dari kulit batang sawo. 


\section{METODE PENELITIAN}

\section{Ekstraksi}

Kulit buah sawo diambil dari tanaman utuh, dicuci dengan air mengalir untuk menghilangkan kotoran pada kulit. Setelah sampel dicuci dilakukan pemotongan atau perajangan sampel. Sampel kulit buah sawo dikeringkan $55^{\circ} \mathrm{C}$ menggunakan oven. Simplisia kulit buah sawo yang telah diperoleh diekstraksi dengan metode maserasi menggunakan pelarut metanol selama $2 \times 24$ jam. Ekstrak metanol yang diperoleh disaring dan dipekatkan menggunakan rotary evaporator hingga diperoleh ekstrak kering.

\section{Fraksinasi}

Sebanyak 10 gram ekstrak kering kulit buah sawo dilarutkan dengan $20 \mathrm{~mL}$ n-heksana dan dimasukkan ke dalam erlenmeyer bertutup lalu distrirer, kemudian disaring. Ekstrak yang tidak larut dimasukkan kembali ke erlenmeyer bertutup kemudian ditambahkan n-heksana dan distirer kembali. Proses tersebut diulang hingga larutan bening. Setelah didapatkan fraksi tersebut diuapkan pelarutnya hingga kental dan dikeringkan. Dilanjutkan proses yang sama dengan pelarut etil asetat.

\section{Identifikasi Metabolit sekunder}

\section{Uji Alkaloid}

Penampakan bercak noda pada plat KLT menggunakan pereaksi dragendroff dengan hasil positif apabila terdapat noda berwarna merah bata, jingga atau coklat (Pratiwi, 2014).

\section{Uji Antrakuinon}

Penampakan bercak noda pada plat KLT menggunakan pereaksi KOH $10 \%$ dengan hasil positif apabila terdapat noda berwarna kuning terang pada UV $366 \mathrm{~nm}$ (kkotakemori \& Okada, 1966)

\section{Uji Kumarin}

Bercak noda pada plat KLT menggunakan pereaksi KOH 10\% dengan hasil positif apabila terdapat noda berflouresensi biru pada UV $366 \mathrm{~nm}$ (Prabowo, 2013) 


\section{Uji Triterpen}

Penampakan bercak noda pada plat KLT menggunakan pereaksi Liebermann Bourchard dengan hasil positif apabila terdapat noda berwarna ungu yang teramati pada sinar tampak, dan secara visual berwarna merah (Fransworth, 1966).

\section{Uji Steroid}

Penampakan bercak noda pada plat KLT menggunakan pereaksi Liebermann Bourchard dengan hasil positif apabila terdapat bercak noda berpendar berwarna biru pada UV $366 \mathrm{~nm}$, dan secara visual terdapat noda berwarna hijau (Fransworth, 1966).

\section{Uji Folifenol}

Penampakan bercak noda pada plat KLT menggunakan pereaksi $\mathrm{FeCl}_{3} 10 \%$ dengan hasil positif apabila terdapat noda berwarna hitam, hijau, merah, ungu, atau biru yang kuat teramati secara visual (Harborne, 1996)

\section{Uji Flavanoid}

Penampakan bercak noda pada plat KLT menggunakan pereaksi sitoborat dengan hasil positif apabila terdapat noda berfluoresensi berwarna hijau kekuningan yang teramati pada UV 366 nm (Markham, 1982).

\section{Pengujian Aktivitas Antibakteri}

Pengujian aktivitas antibakteri dilakukan dengan membuat medium NA terlebih dahulu. Kemudian dilakukan proses sterilisasi alat dan bahan dengan menggunakan autoklaf pada suhu $121{ }^{\circ} \mathrm{C}$ selama 15 menit. Selanjutnya dilakukan pembuatan biakan bakteri dengan menanam bakteri uji diatas permukaan medium NA dengan menggunakan metode agar miring yang telah memadat dalam tabung reaksi, yang kemudian diinkubasi dengan menggunakan inkubator pada suhu $37^{\circ} \mathrm{C}$ selama $1 \times 24$ jam. Setelah diinkubasi dilanjutkan dengan pembuatan suspensi bakteri menggunakan $\mathrm{NaCl}$ 0,9\% hingga diperoleh pengenceran 1:40.

Sampel ditotolkan pada plat KLT, dielusi dalam chamber dengan fase gerak n-heksan : etil asetat dengan perbandingan 2:3, 3:3, 3:4, 3:5 dan 7:3. Plat KLT yang telah dielusi selanjutnya diamati dengan lampu UV254 nm dan UV366 nm, kemudian ditempelkan pada mediun NA yang telah diinokulasi dengan $200 \mu \mathrm{L}$ bakteri. Media didiamkan selama 20 menit, diberi tanda pada bagian bawahnya, 
lalu plat diangkat. Media diinkubasi pada suhu $37^{\circ} \mathrm{C}$ selama 24 jam. Media diamati bila ada bercak pada plat KLT tersebut yang memiliki aktivitas antibakteri.

\section{Pengujian Aktivitas Antioksidan}

Sampel ditotolkan pada plat KLT, dielusi dalam chamber dengan fase gerak n-heksan : etil asetat dengan perbandingan 9:1, 8:2, 7:3, 6:4, dan 5:5. Eluen tersebut di jenuhkan, ekstrak tersebut kemudian dielusi hingga eluen mencapai garis batas Setelah elusi selesai plat KLT dikeringkan dan diamati dengan lampu UV $254 \mathrm{~nm}$ dan UV $366 \mathrm{~nm}$. Kemudian plat tersebut disemprot dengan DPPH dan dilihat noda yang aktif sebagai antioksidan.

\section{HASIL DAN PEMBAHASAN}

\section{Identifikasi Metabolit Sekunder}

Berdasarkan hasil identifikasi golongan senyawa metabolit sekunder terhadap fraksi etil asetat kulit buah sawo diperoleh hasil bahwa terdeteksinya beberapa golongan senyawa metabolit sekunder, diantaranya yaitu antrakuinon, kumarin, triterpen, alkaloid, folifenol, dan flavanoid. Hasil uji metabolit sekunder dapat dilihat pada Tabel 1 .

Tabel 1. Identifikasi Golongan Metabolit Sekunder Fraksi Etil Asetat Kulit Buah Sawo

\begin{tabular}{|c|c|c|c|}
\hline Golongan senyawa & Reagen & Hasil & Keterangan \\
\hline Antrakuinon & $\mathrm{KOH} 10 \%$ & + & $\begin{array}{l}\text { Noda berwarna kuning terang } \\
\text { pada UV } 366 \mathrm{~nm}\end{array}$ \\
\hline Kumarin & & + & $\begin{array}{l}\text { Noda berwarna berflouresensi } \\
\text { biru pada UV } 366 \mathrm{~nm}\end{array}$ \\
\hline Triterpen & $\begin{array}{l}\text { Liebermann } \\
\text { Bourchard }\end{array}$ & + & $\begin{array}{c}\text { Noda berwarna ungu setelah } \\
\text { dipanaskan }\end{array}$ \\
\hline Steroid & & - & Noda berpendar berwarna biru \\
\hline Alkaloid & dragendroff & + & Noda berwarna coklat \\
\hline polifenol & $\mathrm{FeCl}_{3} 10 \%$ & + & Noda berwarna hitam dan biru \\
\hline Flavanoid & Sitoborat & + & $\begin{array}{c}\text { Noda berwarna hijau } \\
\text { kekuningan }\end{array}$ \\
\hline
\end{tabular}

Keterangan:

(+): Teridentifikasi metabolit sekunder

(-) : Tidak teridentifikasi metabolit sekunder 


\section{Pengujian Aktivitas Antibakteri}

Berdasarkan hasil pengujian aktivitas antibakteri menunjukkan bahwa fraksi etil asetat kulit buah sawo memiliki aktivitas sebagai antibakteri terhadap bakteri Escherichia coli dan Staphylococcus aureus. Hal ini ditandai dengan terbentuknya zona bunuh dan zona hambat pada bercak plat KLT. Hasil pengujian aktivitas antibakteri fraksi etil asetat kulit buah sawo menunjukan nilai Rf yang berbedabeda pada tiap eluen terhadap beberapa bakteri seperti yang dilihat pada Tabel 2 dan Gambar 1

Tabel 2. Nilai Rf Zona Bunuh dan Zona Hambat Fraksi Etil Asetat Kulit Buah

\begin{tabular}{|c|c|c|c|c|}
\hline \multirow{2}{*}{$\begin{array}{l}\text { Perbandingan } \\
\text { eluen } \\
\text { (H:E) }\end{array}$} & \multicolumn{2}{|c|}{ E.coli } & \multicolumn{2}{|c|}{ S.aureus } \\
\hline & Zona bunuh & $\begin{array}{c}\text { Zona } \\
\text { Hambat }\end{array}$ & Zona bunuh & $\begin{array}{c}\text { Zona } \\
\text { hambat }\end{array}$ \\
\hline $2: 3$ & & $(\operatorname{Rf} 0,08)$ & & $(\operatorname{Rf} 0,08)$ \\
\hline $3: 3$ & $(\operatorname{Rf} 0,16)$ & & & $(\operatorname{Rf} 0,08)$ \\
\hline $3: 4$ & $(\operatorname{Rf} 0,08)$ & & $(\operatorname{Rf} 0,16)$ & \\
\hline $3: 5$ & $(\operatorname{Rf} 0,08)$ & & & $(\operatorname{Rf} 0,08)$ \\
\hline
\end{tabular}
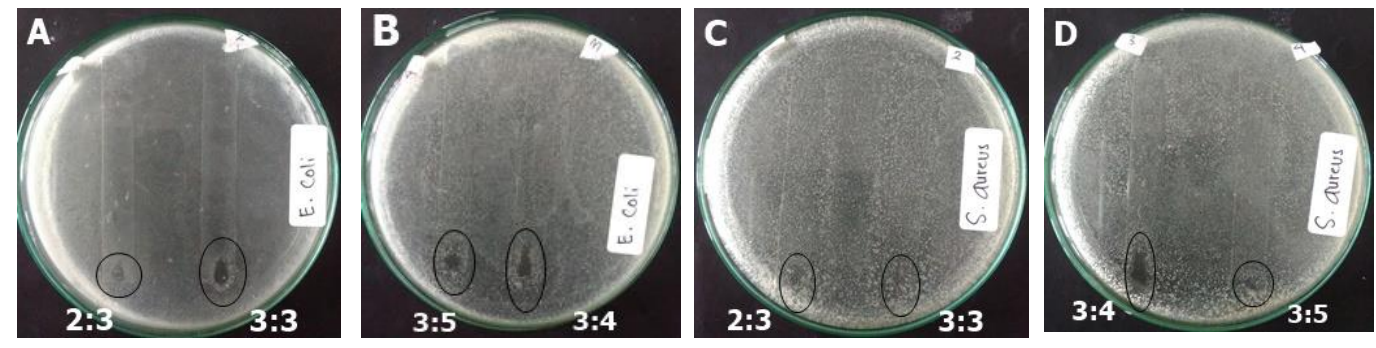

Gambar 1. Uji Aktivitas Antibakteri Fraksi Kulit Buah Sawo Terhadap Bakteri Escherichia coli (A eluen H:E 2:3, 3:3), (B eluen H:E 3:4, 3:5), Staphylococcus aureus (C eluen H:E 2:3, 3:3), (D eluen H:E 3:4, 3:5)

Aktivitas antibakteri pada fraksi etil asetat kulit buah sawo dimungkinkan karena adanya kandungan golongan senyawa metabolit sekunder yang dapat berkhasiat sebagai antibakteri, seperti fenolik, alkaloid, dan flavanoid (Astawan, 2011 dan Ningrum, 2013). 


\section{Pengujian Aktivitas Antioksidan}

Penentuan aktivitas antioksidan senyawa dalam fraksi kulit buah sawo dilakukan menggunakan metode KLT bioautografi dengan penyemprotan menggunakan larutan DPPH. KLT merupakan teknik yang digunakan untuk memisahkan campuran komponen berdasarkan distribusi komponen tersebut diantara dua fase, yaitu fase diam dan fase gerak (Khopka, 2002). Hasil pemisahan menggunakan KLT tidak terlalu jelas bila diamati secara langsung, karena larutannya tidak berwarna, oleh karena hasil pemisahan diamati di bawah sinar UV dan dapat dilihat pada gambar 2. Spot yang terbentuk ditandai dengan pensil atau lingkaran.

A

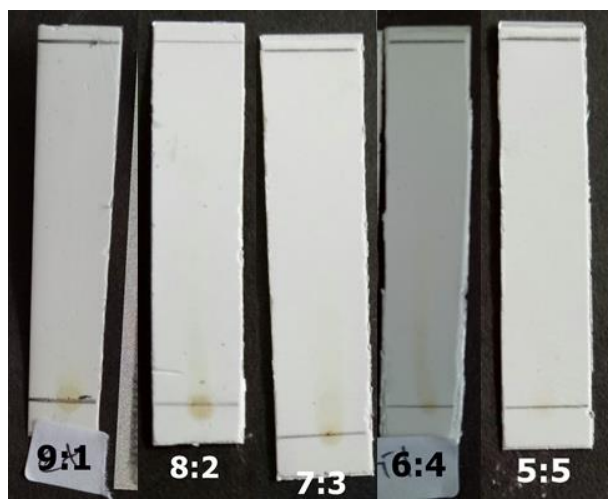

$\mathrm{C}$

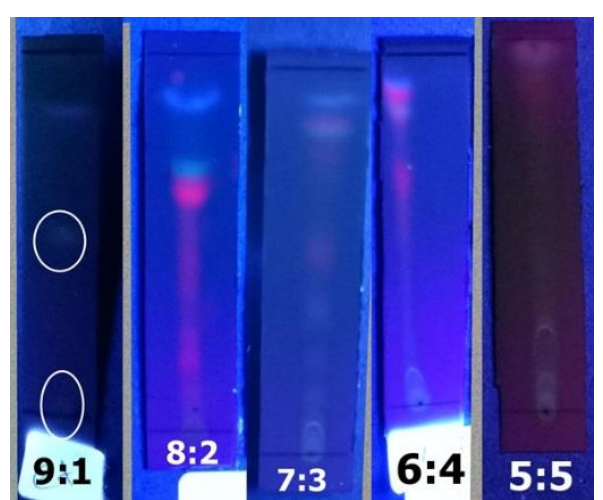

$\mathrm{B}$

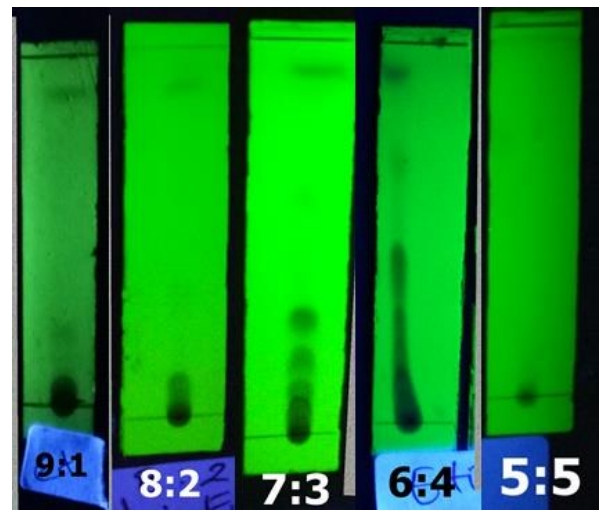

$\mathrm{D}$

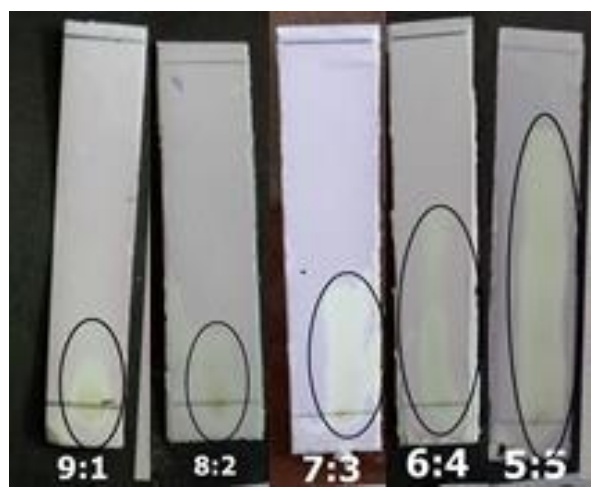

Gambar 2. (A) Hasil Pemisahan Fraksi Etil Asetat Kulit Buah SawoMenggunakan Eluen Heksan:Etil Asetat Dengan Perbandingan 9:1,8:2, 7:3, 6:4, 5:5.; (B) Hasil Pemisahan Fraksi Etil Asetat Kulit Buah Sawo Menggunakan Eluen Heksan:Etil Asetat Dengan Perbandingan 9:1,8:2, 7:3, 6:4, 5:5 Dilihat Menggunakan Lampu UV 254 nm; (C) Hasil Pemisahan Fraksi Etil Asetat Kulit Buah Sawo Menggunakan Eluen Heksan:Etil Asetat Dengan Perbandingan 9:1,8:2, 7:3, 6:4, 5:5 Dilihat Menggunakan Lampu UV 366nm; (D) Hasil Pemisahan Fraksi Etil Asetat Kulit Buah Sawo Menggunakan Eluen Heksan:Etil Asetat Dengan Perbandingan 9:1,8:2, 7:3, 6:4, 5:5 Setelah Disemprot Dengan Larutan DPPH 
Terlihat bahwa padabagian plat yang terdapat spot hasil pemisahan menggunakan KLT, terjadi pemudaran warna ungu larutan DPPH hal ini terjadi karena adanya aktivitas antioksidan. Antioksidan yang terdapat pada fraksi etil asetat kulit buah sawo mampu bereaksi dengan radikal DPPH sehingga menyebabkan radikal tersebut berubah menjadi bentuk tereduksinya (DPPH-H) dan perubahan itulah yang menyebabkan terjadinya pemudaran warna ungu.

Fraksi etil asetat kulit buah sawo memiliki aktivitas antioksidan karena mengandung senyawa flavonoid. Aktivitas antioksidan senyawa flavanoid dikaitkan dengan adanya gugus hidroksil fenolik yang menempel pada struktur kerangkanya. Sifat antioksidan dari flavanoid berasal dari kemampuan untuk mentransfer sebuah elektron ke senyawa radikal bebas dan juga membentuk kompleks dengan logam. Kedua mekanisme itu membuat flavanoid memiliki beberapa efek, diantaranya menghambat peroksidasi lipid, menekan kerusakan jaringan oleh radikal bebas dan menghambat aktivitas beberapa enzim.

\section{Kesimpulan}

Berdasarkan penelitian yang telah dilakukan, dapat diperoleh kesimpulan sebagai berikut:

1. Fraksi etil asetat kulit buah sawo mengandung senyawa golongan metabolit sekunder berupa antrakuinon, kumarin, triterpen, alkaloid, folifenol, dan flavanoid.

2. Fraksi etil asetat kulit buah sawo memiliki aktivitas sebagai antibakteri terhadap bakteri Escherichia coli, dan Staphylococcus aureus.

3. Fraksi etil asetat kulit buah sawo memiliki aktivitas sebagai antioksidan.

\section{DAFTAR PUSTAKA}

Harborne, A. 1998. Phytochemical methods a guide to modern techniques of plant analysis: Springer Science \& Business Media

Khopkar SM. 2002. Konsep Dasar Kimia Analitik . Jakarta: UI-Press

Kulkarni, A.P., R.S. Policegoundra \& S.M Aradhya. 2006. Chemical Compotion and Antioxidant Activity of Sapota (Achras sapota L) Fruit. Journal Of Food Biochemistry 31: 399-414

Nelson JL. Bernstein PS, Schmidt MC, Von Tress MS, dan Askew EW. 2007. Dietary modification and moderate antioxidant supplementation defferently 
affect serum carotenoids, antioxidants level and marker of oxidatife stress in older humans. J.Nutr 133:3177-3123

Ningrum, prihatin. 2013. Uji Daya Antibakteri Ekstrak Sawo Manila Terhadap E.coli dan Implemantasinya dalam Pembelajaran Peranan Bakteri. FKIP Biologi; Universitas Tanjung Pura.

Pratiwi, Sylvia. 2008. Mikrobiologi Farmasi. EGC. Jakarta. 